\title{
TANTANGAN PEMBENTUKAN KELOMPOK USAHA BERSAMA (KUBe) DI DESA JAGO
}

\author{
Dewi Fitri Nur'afuddin ${ }^{1}$, Muhammad Suprodi², dan Ni Ketut Santi Rahayu ${ }^{3}$, Ni Komang Tri

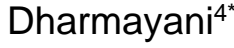 \\ ${ }^{1}$ Fakultas MIPA Universitas Mataram \\ ${ }^{2}$ Fakultas Fatepa Universitas Mataram \\ ${ }^{3}$ Fakultas Tehnik Universitas Mataram \\ ${ }^{4}$ Fakultas FKIP Universitas Mataram \\ ${ }^{*}$ Co-Author: tri.dharmayani@unram.ac.id
}

\begin{abstract}
ABSTRAK. Desa Jago adalah desa yang terletak di kecamatan Praya, kabupaten Lombok Tengah Provinsi Nusa Tenggara Barat. Luas wilayah Desa Jago adalah $753 \mathrm{Ha}$ dengan kepadatan penduduk mencapai 15,791 jiwa yang tersebar di 20 Dusun. Mayoritas tingkat pendidikan masyarakat Desa Jago adalah tamat sekolah dasar/sederajat. Desa Jago memiliki ciri khas yang didominasi oleh masyarakat yang bermata pencaharian dengan bertani dan beternak. Warga Desa Jago merupakan warga yang memiliki keterampilan yang cukup baik dalam hal menganyam, membuat kerupuk, membuat cilok, merajut, dan lain sebagainya. Namun, warga Desa Jago memiliki kendala dalam mengasah keterampilan tersebut menjadi suatu usaha dikarenakan kurangnya modal usaha, kurangnya partisipatif masyarakat dalam berusaha, serta kurangnya pengetahuan masyarakat dalam hal promosi. Maka perlu dilaksanakan Program Kelompok Usaha Bersama (KUBe) di Desa Jago dengan tujuan untuk meningkatkan pendapatan atau peningkatan ekonomi yang nantinya berdampak pada menurunnya tingkat kemiskinan. Adapun metode yang dilakukan dalam membentuk KUBe adalah sosialisasi $\mathrm{KUBe}$, sosialisasi pemanfaatan hasil pertanian, pelatihan membuat produk, pembentukan KUBe, penyerahan proposal ke Dinas Sosial. Sosialisasi dan pelatihan dilaksanakan di Kantor Desa dengan peserta berasal dari setiap dusun. Kegiatan pembentukan KUBe ini dilaksanakan dengan metode survey dengan turun langsung ke masyarakat (door to door) dengan acuan Basis Data Terpadu (BDT). Adapun KUBe yang berhasil dibentuk berjumlah 3 yaitu Mele Maju II, Kerupuk Mandiri, dan Mawar Melati.
\end{abstract}

Kata Kunci: Desa Jago, Kelompok Usaha Bersama, Pemanfaatan Hasil Pertanian

ABSTRACT. Jago Village is a village located in Praya Sub-district, Central Lombok District of West Nusa Tenggara province. The area of Jago village is $753 \mathrm{Ha}$ with a population density of 15.791 people spread in 20 Dusun. The majority of the education level of Jago Village is elementary school/equivalent. Jago Village has a characteristic that is dominated by people who are on the livelihood of farming and livestock. Jago villagers are citizens who have enough skills in weaving, making crackers, making cilok, knitting, and so forth. However, the villagers have constraints in honing such skills into an effort due to lack of business capital, lack of participatory community in trying, as well as lack of knowledge of society in terms of promotion. The Joint Business Group Program (KUBe) is required in Jago village with the aim to increase income or economic increase, which later impacts on declining levels of poverty. The method that is done in forming $K U B e$ is the socialization of KUBe, socialization of agricultural product utilization, training of 
making products, establishment of KUBe, submission of proposals to the social service. Socialization and training conducted in the village office with participants from each hamlet. The establishment of KUBe is carried out by the survey method by falling directly to the community (door to door) with the reference of integrated Database (BDT). The KUBe is successfully formed amounting to 3 namely Mele Maju II, Crackers Mandiri, and Rose Jasmine.

Keyword: Jago village, joint business group, agricultural products utilization

\section{PENDAHULUAN}

Desa Jago adalah desa yang terletak di kecamatan Praya, kabupaten Lombok Tengah Provinsi Nusa Tenggara Barat. Luas wilayah desa Jago adalah $753 \mathrm{Ha}$ dengan kepadatan penduduk mencapai 15,791 jiwa yang tersebar di 20 Dusun (Minsani, 2016). Mayoritas tingkat pendidikan masyarakat Desa Jago adalah tamat sekolah dasar/sederajat. Hal ini mengakibatkan tingkat taraf perekonomian masyarakat Desa Jago masih dibilang cukup rendah. Hal ini dapat dilihat dari data yang didapatkan di kantor desa setempat bahwa sebanyak 1,121 masyarakat desa Jago yang berprofesi sebagai TKI atau TKW di luar negeri.

Desa Jago memiliki ciri khas dimana wilayahnya didominasi oleh pertanian dan peternakan. Oleh karena itu, mata pencaharian masyarakat Jago didominasi oleh bertani dan beternak. Hasil pertanian dan peternakan dari Desa Jago cukup melimpah seperti padi, cabai, tomat, kelapa, dan lain sebagainya. Namun, hasil pertanian ini kurang dimanfaatkan dikarenakan kurangnya pemahaman masyarakat dalam mengolahnya.

Warga Desa Jago merupakan warga yang memiliki keterampilan yang cukup baik dalam hal menganyam, membuat kerupuk, membuat cilok, merajut, dan lain sebagainya. Namun, warga Desa Jago memiliki kendala dalam mengasah keterampilan tersebut menjadi suatu usaha dikarenakan kurangnya modal usaha, kurangnya partisipatif masyarakat dalam berusaha, serta kurangnya pengetahuan masyarakat dalam hal promosi.

Dari penjelasan diatas, maka perlu dilaksanakan Program Kelompok Usaha Bersama (KUBe) di Desa Jago. KUBe merupakan program langkah pemberdayaan fakir miskin yang dilaksanakan oleh pemerintah. Masyarakat dapat memanfaatkan dan mengikuti KUBe yang di sesuaikan dengan keahlian yang didukung dengan kondisi lingkungan yang dilaksanakan secara berkelompok untuk menangani permasalahan kemiskinan yang sudah mengakar dalam sebuah masyarakat. KUBe merupakan media pemberdayaan sosial yang diarahkan untuk terciptanya aktifitas sosial ekonomi keluarga masyarakat miskin agar dapat meningkatkan kesejahteraan sosial mereka (Kementerian Sosial RI, 2016). Tujuan dari program Kelompok Usaha Bersama (KUBe) adalah untuk meningkatkan pendapatan atau peningkatan ekonomi yang nantinya berdampak pada menurunnya tingkat kemiskinan. Selain itu, dengan adanya KUBe diharapkan dapat meningkatkan pengetahuan masyarakat dalam memanfaatkan potensi yang ada, meningkatkan kemampuan dalam berintraksi antara satu dengan yang lain sehingga dapat meningkatkan produktifitas anggotanya, meningkatkan relasi sosial yang harmonis, memecahkan masalah sosial yang dialami serta menjadi wadah pengembangan usaha bersama. Menurut (Zulkarnain, 2010) bahwa peran KUBe yaitu menjamin bahwa dalam menjalankannya, setiap anggota saling berinteraksi sehingga tujuan kelompok dapat tercapai. Terdapat beberapa penghambat dalam menjalankan program Kelompok Usaha Bersama 
(KUBe) seperti kurang pahamnya masyarakat tentang apa itu Kelompok Usaha Bersama (KUBe), tidak ada kemauan untuk mengambil resiko, kesibukan dalam mengurus rumah tangga dan mengurus sawah, tidak berjalan jika tidak didampingi. Oleh karena itu, permasalahan inilah yang melatarbelakangi mahasiswa KKN Tematik Universitas Mataram bertujuan sebagai fasilitator guna menghubungkan masyarakat dengan pemerintah dan membantu pemerintah dalam mengentaskan kemiskinan.

\section{METODE PELAKSANAAN}

Metode yang digunakan dalam pembentukan KUBe ini adalah sosialisasi serta mengadakan pelatihan.

\section{Waktu dan Tempat}

Kegiatan KKN Tematik Universitas Mataram dilaksanakan mlai tanggal 23 Desember 2019 sampai dengan 06 Februari 2020 di Desa Jago Kecamatan Praya Kabupaten Lombok Tengah Provinsi Nusa Tenggara Barat.

\section{Metode sosialisasi}

Sosialisasi di Desa Jago ini merupakan sosialisasi pemanfaatan potensi desa yaitu hasil pertanian serta limbah organik yang dapat diolah menjadi suatu produk yang bernilai jual tinggi seperti pupuk kompos dari kotoran ayam, permen jelly tomat, bon cabe, sabun arang. Selain itu, dilakukan sosialisasi tentang KUBe untuk menambah wawasan masyarakat terkait KUBe itu sendiri sehingga masyarakat akan tertarik untuk membentuk KUBe demi meningkatkan taraf perekonomiannya.

\section{Metode pelatihan}

Pelatihan di Desa Jago dilaksanakan untuk mengajarkan masyarakat mempraktikkan materi sosialisasi sehingga masyarakat lebih memahami tujuan dari sosialisasi tersebut.

\section{Pembentukan KUBe}

Pembentukan KUBe di Desa Jago dilakukan dengan metode turun langsung ke masyarakat (door to door) untuk menjelaskan kembali ke masyarakat terkait KUBe seperti pengertian, tujuan dan syarat-syarat yang bisa ikut dalam KUBe tersebut.

\section{Peenyerahan Proposal KUBe ke Dinas Sosial}

Pembuatan proposal dilakukan oleh mahasiswa KKN kemudian dikirimkan ke Dinas Sosial sebagai permohonan bantuan dana usaha yang selanjutnya akan divalidasi kembali.

\section{HASIL DAN PEMBAHASAN}

Program KKN Tematik Universitas Mataram dilakukan secara terstruktur dan melibatkan masyarakat secara langsung.

\section{Pelaksanaan Program Pemberdayaan Masyarakat}

Kegiatan pemberdayaan masyarakat ini dimulai dengan persiapan program yang meliputi penyebaran surat undangan kepada seluruh kepala dusun untuk mengirimkan dua orang delegasi untuk mengikuti sosialisasi dan pelatihan. 


\section{Sosialisasi}

Kegiatan sosialisasi dihadiri oleh warga yang diminta menjadi delegasi oleh Kepala dusun di setiap masing-masing dusun. Kegiatan sosialisasi ini dilaksanakan selama 3 hari berturut-turut. Adapun jumlah peserta sosialisasi berjumlah 15 orang. Melihat dari jumlah tersebut memang kurang dari ekspektasi bahkan jumlahnya kurang dari setengah total yang seharusnya. Hal ini terjadi dikarenakan kurangnya minat masyarakat dalam mengikuti kegiatan-kegiatan sosialisasi yang tidak disertai uang transportasi, masyarakat lebih memilih untuk sibuk di sawah menanam padi, masyarakat juga kurang berpartisipasi dalam hal kegiatan yang bersifat kelompok, masyarakat juga banyak yang bersifat individualis. Oleh karena itu, hal inilah yang merupakan tantangan terbesar mahasiswa KKN dalam melaksanakan pembentukan KUBe di Desa Jago.

Adapun sosialisasi-sosialisasi yang dilaksanakan yaitu sosialisasi terkait KUBe yang narasumbernya adalah Dinas Sosial Kabupaten Lombok Tengah, sosialisasi pembuatan pupuk kompos dari kotoran ayam dengan narasumbernya adalah Dinas Pertanian Kabupaten Lombok Tengah, dan sosialisasi pemanfaatan potensi desa dengan narasumbernya adalah mahasiswa KKN Tematik Universitas Mataram.

Adapun sosialisasi ini dilaksanakan dengan cara ceramah dan tanya jawab. Sosialisasi ini dimulai dengan menjelaskan materi-materi yang akan ditampilkan pada proyektor. Adapun materimateri yang disampaikan adalah penjelasan tentang KUBe, pemanfaatan kotoran ayam menjadi kompos, pemanfaatan tomat, cabai dan arang tempurung kelapa menjadi sabun mandi. Setelah itu, diberikan waktu kepada peserta sosialisasi untuk bertanya. Tujuan dari sosialisasi ini dilakukan adalah untuk membuka pola fikir masyarakat dan menambah wawasan masyarakat dalam memanfaatkan potensi desa serta menarik simpati masyarakat sehingga masyarakat berkeingunan untuk membentuk KUBe.

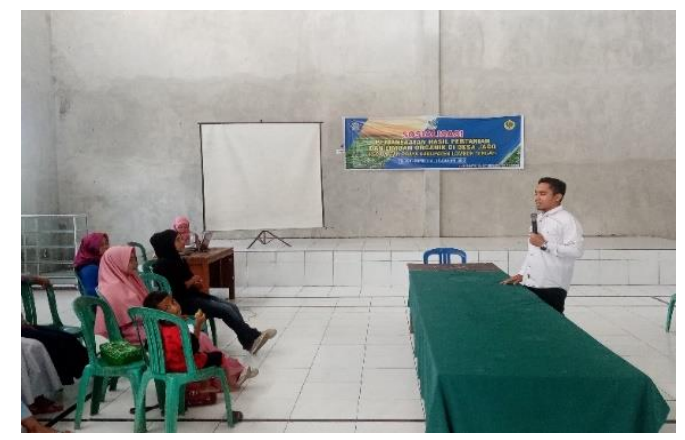

Gambar 1.Sosialisasi KUBe oleh Dinas Sosial Kabupaten Lombok Tengah

\section{Pelatihan}

Kegiatan pelatihan dilakukan dengan mempraktikkan materi-materi yang telah disampaikan saat sosialisasi yang didampingi oleh narasumbernya langsung. Adapun alat dan bahan yang diperlukan dalam melakukan praktik tersebut disiapkan oleh mahasiswa KKN. Dikarenakan alat dan bahannya terbatas maka praktik dilakukan oleh 2 orang perwakilan peserta dan disampingi 2 orang narasumber dan peserta lainnya menyaksikan cara pembuatan tanpa mempraktikkannya. 


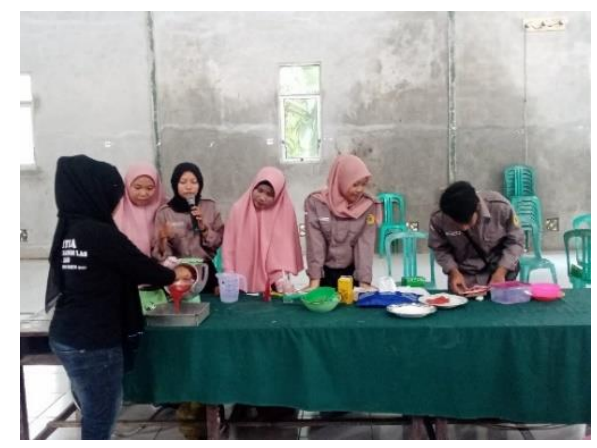

Gambar 2. Pelatihan pembuatan produk

\section{Pembentukan KUBe}

Kegiatan pembentukan KUBe ini dilaksanakan dengan metode survey dengan turun langsung ke masyarakat (door to door) dengan acuan Basis Data Terpadu (BDT). BDT merupakan sebuah sistem basis data elektronik yang berisi informasi rumah tangga miskin dan rentan di Indonesia. Data ini, dirancang khusus untuk mendukung kementerian dan lembaga dalam perencanaan program perlindungan sosial dan penanggulangan kemiskinan. Hal ini dilakukan untuk memastikan kebenaran data yang mengacu pada BDT. Survei dimulai dengan mencari 10 anggota dalam 1 kelompok yang ingin mengajukan program KUBe. Setelah didapatkan calon penerima KUBe yang memenuhi indikator penerima KUBe maka dilakukan pengumpulan persyaratan dan data yang dibutuhkan seperti Penduduk (KTP), Kartu Keluarga (KK). Adapun kegiatan pembentukan KUBe dapat dilihat pada gambar 3 .

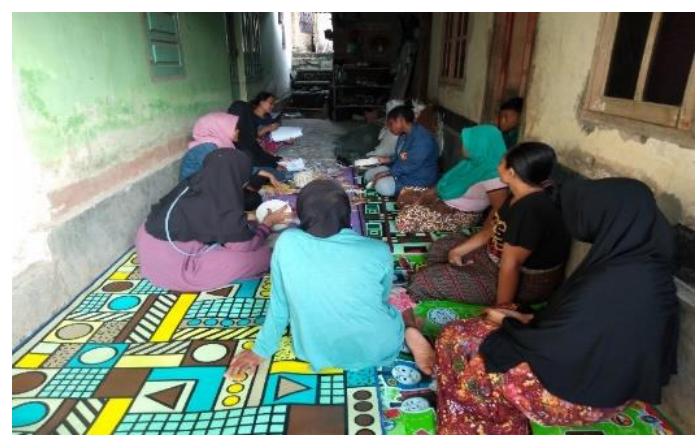

Gambar 3. Pembentukan KUBe

Berdasarkan hasil survei lapangan yang telah dilakukan, berikut ini merupakan KUBE yang telah terbentuk tahun 2020 :

Tabel 1. Kelompok Usaha Bersama yang berhasil terbentuk

\begin{tabular}{lllcl}
\hline No & Nama Kelompok & Jenis Usaha & $\begin{array}{c}\text { Jumlah } \\
\text { Anggota }\end{array}$ & Dusun \\
\hline 1. & Mele Maju II & Ternak Sapi & 10 & Panti \\
\hline 2. & Mawar Melati & Anyaman Rotan & 10 & Panti Babas \\
\hline 3. & Kerupuk Mandiri & Kerupuk & 10 & Panti Babas \\
Sumber: Laporan Progress Program Kerja KKN Tematik Universitas Mataram &
\end{tabular}




\section{Penyerahan Proposal KUBe}

Proposal KUBe dibuat oleh mahasiswa KKN Universitas Mataram dengan mengikuti format proposal dari Dinas Sosial setempat. Kemudian, proposal tersebut akan diserahkan ke Dinas Sosial untuk divalidasi lebih lanjut.

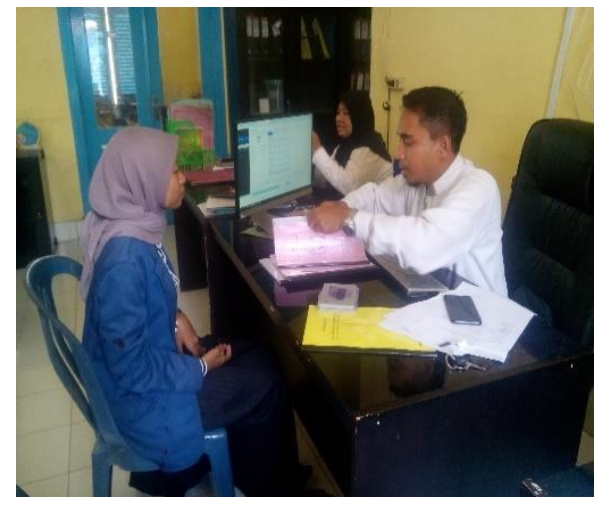

Gambar 4. Penyerahan Proposal KUBe ke Dinas Sosial Kabupaten Lombok Tengah

\section{KESIMPULAN}

Berdasarkan penjelasan diatas dapat disimpulkan bahwa masyarakat Desa Jago merupakan masyarakat yang memiliki keterampilan. Namun, untuk memiliki terkendala dalam modal dan masyarakat yang lebih memilih untuk bertani. Oleh karena itu, perlu dilakukan pembentukan KUBe untuk meningkatkan taraf perekonomian masyarakat Desa Jago.

Diharapkan kepada pemerintah untuk memberikan pengarahan serta pemahaman lebih lanjut terkait KUBe. Selain itu, untuk KUBe yang telah terbentuk dalam berjalan lancer dan menjalankan program-program kerja yang dapat mengentaskan kemiskinan sehingga masyarakat dapat meningkatkan kesejahteraan hidupnya.

\section{UCAPAN TERIMA KASIH}

Ucapan terima kasih disampaikan kepada Universitas Mataram, Lembaga Penelitian dan Pengabdian Masyarakat dan Desa Jago atas dukungan yang telah diberikan sehingga program kerja KKN Tematik dapat berjalan dengan lancar.

\section{DAFTAR REFERENSI}

Basis Data Terpadu 2015. http://tnp2k.go.id ( Diakses pada 3 Februari 2020).

Kementrian Sosial Republik Indonesia. https://kemsos.go.id/kube (Di akses pada 3 Februari 2020).

Minsani. 2016. Profil Desa Jago. https://Dokumen.Tips/Documents/Profil-Desa-Jago.Html (Diakses Pada 08 Februari 2020).

Zulkarnain, Wildan. (2013). Dinamika Kelompok (Latihan Kepemimpinan Pendidikan). Jakarta: PT Bumi Aksara. 